Zoologica Poloniae (2011) 56/1-4: 19-33

DOI: $10.2478 / \mathrm{v} 10049-011-0005-7$

\title{
ORALLY ADMINISTERED MELATONIN AND THE ACCUMULATION AND TOXICITY OF CADMIUM IN THE BANK VOLE (MYODES GLAREOLUS)
}

\author{
Ewa ChweŁatiuk and Tadeusz WŁostowski
}

University of Bialystok, Institute of Biology, Świerkowa 20b, 15-950 Białystok, Poland

e-mail address: chwelat@uwb.edu.pl; twlostow@uwb.edu.pl

\begin{abstract}
Animal gender and age significantly influence the accumulation and toxicity of heavy metals, including cadmium $(\mathrm{Cd})$. The aim of this study was to determine the effect of orally administered melatonin $(6 \mu \mathrm{g} / \mathrm{ml})$, a known antioxidant and metal chelator, on $\mathrm{Cd}$ accumulation and toxicity in one month old females and males (young) and five months old bank voles (old) exposed to dietary Cd $(100 \mu \mathrm{g} / \mathrm{g})$ for six weeks. Compared to the $\mathrm{Cd}$ alone group, melatonin co-treatment brought about a decrease of $\mathrm{Cd}$ concentration in the liver (17\% and 20\%) and kidneys (39\% and 36\%) of young female and male bank voles, respectively, while in old animals increased $\mathrm{Cd}$ accumulation in liver $(65 \%)$ and kidneys $(81 \%)$ and enhanced consumption of Cdcontaminated food $(136 \%)$ without any effect on their body mass. The results suggest that orally administered melatonin together with cadmium in young bank voles reduces tissue $\mathrm{Cd}$ accumulation possibly through forming stable complexes with this metal but in older rodents, melatonin increases concentration of the metal through increasing consumption of Cd-contaminated food.
\end{abstract}

Key words: cadmium accumulation, melatonin, metal chelation, gender, age

\section{INTRODUCTION}

According to human industrial and agricultural activities, contamination of the environment continues to grow (SATARUg et al. 2003, WAisberg et al. 2003). Heavy metals are one of the most hazardous pollutants of widespread distribu- 
tion in the environment, one of which is cadmium $(\mathrm{Cd})$. This toxic element does not undergo the process of biodegradation, it constantly accumulates in the environment and it is deleterious for all living biota, including humans. In the general population, the main source of $\mathrm{Cd}$ is food contaminated with the metal (Zalups and Ahmad 2003). After ingestion, cadmium is absorbed by the gastrointestinal tract and is distributed primarily to the liver and kidneys where it induces the synthesis of metallothionein (MT), a low-molecular-weight protein rich in cysteinyl residues with high affinity for this metal (KLAASSEN et al. 1999, Nordberg and Nordberg 2000). It is commonly thought that cadmium bound to MT as a metal-protein complex (CdMT) is toxicologically inert (KLAASSEN et al. 1999). When the amount of cadmium in the liver and kidneys exceeds the binding capability of MT, the non-MT-bound ions are believed to cause hepatoand nephrotoxicity (Goyer et al. 1989; Nordberg and Nordberg 2000). Since elevated levels of renal and hepatic $\mathrm{Cd}$ can cause renal and hepatic dysfunction (Min et al. 1986), factors influencing Cd absorption and tissue accumulation are important aspects of Cd toxicity.

Cadmium absorption and accumulation in the liver and kidneys depends on a number of factors: animal age and gender (RUMmLer et al. 1989, Bonda et al. 2004), dose of cadmium, the route and duration of exposure, dietary intake of several mineral elements (e.g. Fe, $\mathrm{Zn}$ and Ca) (Brzóska and Moniuszko-JAKoniuk 1998, Reeves and Chaney 2004), proteins and chelating agents (Groten et al. 1991, Andersen et al. 2004a, b), and photoperiod. For example, bank voles (Myodes glareolus) exposed subchronically to dietary $\mathrm{Cd}$ under a short photoperiod accumulate more $\mathrm{Cd}$ (up to $100 \%$ in the liver and $65 \%$ in the kidneys) than voles raised under a long photoperiod despite the fact that short and long photoperiod animals ingest similar amounts of cadmium (WŁosTOWSKi et al. 2000, 2004). Recent data suggest that melatonin may be responsible for the effect of photoperiod (ChwetatiuK et al. 2005).

Melatonin (N-acetyl-5-methoxytrypthamine) is synthesized rhythmically, mainly in the pineal gland, with maximal synthesis during the dark period of the light-dark cycle. It is an ubiquitously acting indoleamine with varied functions (KARBOWNiK et al. 2001). Among them are antioxidant properties and the ability to scavenge free radicals with higher effectiveness than ascorbic acid, vitamin E, or glutathione (GSH) (Pieri et al. 1995; Reiter et al. 2007). Apart from antioxidant properties, this molecule is able to form in vitro complexes with $\mathrm{Cd}$ and other metals (Limson et al. 1998). Thus, it is of a great importance to find out whether orally administered melatonin together with cadmium influences the accumulation of this metal in tissues of photosensitive bank voles. Therefore, the main purpose of the present study was to determine the effect of orally administered melatonin on tissue cadmium accumulation in one month old female and male M. glareolus and in five months old animals exposed subchronically to dietary $\mathrm{Cd}$. In addition, histological examinations of the kidneys and liver as well as analyses of tissue MT, lipid peroxidation, and Fe were carried out. 


\section{MATERIALS AND METHODS}

\section{Animals and experimental design}

The procedures used in this study were approved by the Local Ethical Committee for conducting an experimental study on laboratory animals (Medical Academy in Białystok). Bank voles used in this study were the $F_{1}$ offspring of wild-caught specimens form the population in Knyszyn Old Forest near Białystok in northeastern Poland. This area was chosen because it has low pollution levels, including heavy metals, thus offspring of animals from this location should have less preadaptations to cadmium. The animals were housed for six weeks in a windowless room with the relative humidity at 50-70\%, automatically regulated temperature $20 \pm 2{ }^{\circ} \mathrm{C}$, and lighting $(16 \mathrm{~h}$ light : $8 \mathrm{~h}$ dark - a long photoperiod) switched on from 06:00 to 22:00 h. All animals were kept in stainlesssteel cages $(44 \times 25 \times 15 \mathrm{~cm})$ lined with peat as an absorptive material, and hay in a nest compartment. Twenty four one month old male and female bank voles (young animals) and 24 five month old bank voles, weighing 10-13 g and 19-25 g respectively, were divided into four treatment groups: 1. Control, 2. Melatonin, 3. Cadmium, and 4. Cd + Melatonin.

Melatonin (Sigma) was dissolved in a minimum volume of ethanol (96\%) and then diluted to $6 \mu \mathrm{g} / \mathrm{ml}$ with distilled water. The selected dose of melatonin was the lowest one that had a similar effect on cadmium accumulation to those observed in bank voles held under a short photoperiod ( $8 \mathrm{~h}$ light : $16 \mathrm{~h}$ dark) (WŁostowsкi et al. 2000, 2004). Water bottles were covered with aluminum foil to protect the melatonin from lightdegradation and their content was changed twice weekly. The control and $\mathrm{Cd}$ alone voles were given distilled water with an equivalent amount of ethanol, the final concentration of which was less than $0.5 \%$. All bank voles were allowed free access to drinking water and food of which intake was measured throughout the study. In addition, an identical amount of apple was offered to all animals ( $3 \mathrm{~g} / \mathrm{vole} / \mathrm{week})$ and was completely eaten. Animals received control (group 1 and 2) or Cd-containing wheat grains (groups 3 and 4). Prior to the experiment, the grains were contaminated with $\mathrm{Cd}$ $(100 \mu \mathrm{g} / \mathrm{g})$ (soaked in $\mathrm{CdCl}_{2}$ solution) (WŁostowski et al. 2004). Atomic absorption spectrophotometry (AAS) analysis of grains revealed that actual levels of Cd were between 98-105 $\mu \mathrm{g} / \mathrm{g}$ dry wt. This dose of $\mathrm{Cd}$ was also used in our previous works (WŁostowski et al. 2005, Chwęatiuk et al. 2005) and chosen to make cadmium accumulation in the liver and kidneys more pronounced. The level of cadmium in grains of control wheat measured by this method was less than $0.05 \mu \mathrm{g} / \mathrm{g}$.

\section{Assays}

At the end of the six week exposure period, the animals were weighed, euthanized by decapitation and the liver, kidneys, and duodenum were removed, rinsed in ice-cold saline and blotted dry. A portion of the liver $(0.25 \mathrm{~g})$ and one 
kidney were transferred to $2.0 \mathrm{ml}$ chilled $0.25 \mathrm{M}$ sucrose and homogenized with a Teflon pestle in a glass homogenizer. Aliquots $(0.2$ and $1.0 \mathrm{ml})$ of the homogenate were taken for determination of lipid peroxidation and $\mathrm{Cd}$ concentrations, respectively. The remaining homogenate was centrifuged at $20000 \times \mathrm{g}$ for $20 \mathrm{~min}$. at $4{ }^{\circ} \mathrm{C}$, and the resulting supernatant was removed for MT assay.

Cadmium determination was performed as described elsewhere (WŁostowsKI et al. 2004). Briefly, the homogenates of the liver and kidneys $(1.0 \mathrm{ml})$ and duodenum were placed in a glass tube with $2.0 \mathrm{ml}$ of concentrated nitric acid. After $20 \mathrm{~h}$ of sample digestion at room temperature, $72 \%$ perchloric acid $(0.5 \mathrm{ml})$ was added and the mixture was heated at $100^{\circ} \mathrm{C}$ for $3 \mathrm{~h}$. Finally, the temperature was raised to $150^{\circ} \mathrm{C}$ and digestion was continued for another $4 \mathrm{~h}$. Deionized water was added to the residue after digestion to a volume of $3.0 \mathrm{ml}$ (first solution). A portion of the first solution $(200 \mu 1)$ was evaporated to dryness in a quartz crucible at $130{ }^{\circ} \mathrm{C}$, and the residue was redissolved in an appropriate amount of deionized water (second solution). Cadmium analyses of these solutions were carried out by electrothermal atomic absorption spectrometry (AAS) using an AAS3 Zeiss Jena instrument with an EA3 furnace attachment. Samples of bovine liver $1577 \mathrm{~b}$ (NIST) were also analyzed in an identical manner to check accuracy of the method. The recovery of Cd was $91-95 \%$.

Metallothionein content was determined by a Cd-saturation method (ONOSAKA and Cherian 1982) with minor modification (WŁostowski and Krasowska, 1999). Briefly, in a $1.5 \mathrm{ml}$ vial, $0.1 \mathrm{ml}$ sample was incubated for $10 \mathrm{~min}$ at room temperature with $1.0 \mathrm{ml}$ Tris-HCL buffer $(0.03 \mathrm{M}, \mathrm{pH} 7.8)$ containing $1.0 \mu \mathrm{g} \mathrm{Cd} / \mathrm{ml}$ as $\mathrm{CdCl}_{2}$. To remove non-MT-bound $\mathrm{Cd}$, bovine hemoglobin (Sigma) $(0.1 \mathrm{ml}$ of a $5 \%$ solution in $\mathrm{H}_{2} \mathrm{O}$ ) was added and the sample was heated for 1.5 min at $95^{\circ} \mathrm{C}$, cooled and centrifuged for $5 \mathrm{~min}$ at $10000 \times \mathrm{g}$. Addition of hemoglobin, heating and centrifugation of the sample was repeated three times. Cd bound to MT in the resulting clear supernatant was determined by electrothermal AAS. MT content was expressed in $\mu \mathrm{g}$ of the protein per gram of wet tissue, assuming that $1 \mathrm{~mol}$ of MT (6600) binds $7 \mathrm{~mol}$ of Cd (Winge and Miklossy 1982).

Lipid peroxidation was assessed by measuring malondialdehyde (MDA) formation, using the thiobarbituric acid (TBA) assay (OHKAWA et al. 1979). To $0.2 \mathrm{ml}$ of the tissue homogenate, $0.2 \mathrm{ml}$ of $8.1 \%$ sodium dodecyl sulphate, $1.5 \mathrm{ml}$ of $20 \%$ acetic acid, $1.5 \mathrm{ml}$ of $0.8 \%$ thiobarbituric acid, and $0.6 \mathrm{ml}$ of distilled water were added and vortexed. The reaction mixture was placed in a water bath at $95^{\circ} \mathrm{C}$ for $1 \mathrm{~h}$. After cooling, $1.0 \mathrm{ml}$ of distilled water and $5.0 \mathrm{ml}$ of butanol/pyridine mixture $(15: 1 \mathrm{v} / \mathrm{v})$ were added and vortexed. After centrifugation, absorbance of the organic phase was determined at $532 \mathrm{~nm}$. Tetraethoxypropane was used to prepare a calibration curve. The results were expressed as TBARS (nmol/g wet wt).

\section{Histological examinations}

One kidney and a portion of the liver from each animal were fixed in $10 \%$ phosphate-buffered formalin, dehydrated in ethanol and xylene, embedded in paraffin, cut into $8 \mu \mathrm{m}$ sections, and stained with hematoxylin and eosin $(\mathrm{H} \& \mathrm{E})$ for microscopic examination. 


\section{Statistical analysis}

Data were expressed as means $\pm \mathrm{SD}$. The values were analyzed by two-way analysis of variance (ANOVA) followed by the Duncan's multiple range test (MS Statistica 5.1). Differences at $\mathrm{p}<0.05$ were considered statistically significant.

\section{RESULTS}

In one month old female and male bank voles the six week exposure to dietary $\mathrm{Cd}(100 \mu \mathrm{g} / \mathrm{g})$ did not affect the final body, liver, and kidneys weights (Table 1). Melatonin treatment had no effect on final body and tissues weights in females, but in males, this molecule reduced significantly the growth of the body as well as liver and kidneys (Table 1). As can be seen in Tables 2 and 3, the accumulation of $\mathrm{Cd}$ in the liver, kidneys, and intestine, as well as hepatic and renal MT concentrations in female and male young bank voles were significantly affected by dietary $\mathrm{Cd}$ and its interaction with melatonin. In males and females exposed to dietary $\mathrm{Cd}$, orally administered melatonin brought about a significant decrease of $\mathrm{Cd}$ accumulation in kidneys $36 \%$ and $39 \%$, liver $20 \%$ and $17 \%$, and in duodenum $40 \%$, respectively, as compared to those in the $\mathrm{Cd}$ alone group. The renal and hepatic MT levels followed a pattern similar to that of the $\mathrm{Cd}$ accumulation. Histological examinations did not reveal any changes in tissues of young males (Table 1). Pathological lesions were observed in kidneys (glomerular swelling and a multifocal tubular degeneration) and less numerous in the liver (infiltration of leucocytes) only in females exposed to dietary $\mathrm{Cd}$ (Table 1), which accumulated considerably more $\mathrm{Cd}$ in tissues than males (Table 2 and 3). In females co-treated with melatonin, no damage to liver and kidneys was seen (Table 1). ANOVA revealed that dietary $\mathrm{Cd}$ and melatonin did not influence the hepatic and renal lipid peroxidation (TBARS) either in females or males of the bank voles (Table 2 and 3).

Dietary $\mathrm{Cd}$ and melatonin co-treatment had no effect on final body, liver and kidneys weights of five months old male bank voles during the sixweek period of the experiment (Table 1). Similar to young animals, old voles hepatic, renal, and intestinal $\mathrm{Cd}$ levels as well as renal and hepatic MT concentrations were significantly affected by dietary $\mathrm{Cd}$ and its interaction with melatonin (Table 4). However, in contrast to one month old bank voles, in five months old rodents co-treated with melatonin, a higher cadmium intake $(136 \%)$ was observed (Table 1). Also, in melatonin co-treated old voles, higher Cd accumulation in the liver $(65 \%)$, kidneys $(81 \%)$, and duodenum $(46 \%)$ was noted in comparison to voles from $\mathrm{Cd}$ alone group (Table 4). The renal and hepatic MT levels followed a pattern similar to that of the $\mathrm{Cd}$ accumulation. In the liver and kidneys, no histopathological lesions and no changes in the level of lipid peroxidation were noted (Table 1 and 4 ). 
Table 1. Body and organ weights, Cd intakes and histopathological changes in the liver and kidney of 1 - and 5-months old bank voles ${ }^{\#}$

\begin{tabular}{|c|c|c|c|c|}
\hline & Control & Melatonin & $\mathrm{Cd}$ & $\begin{array}{l}\mathrm{Cd}+ \\
\text { Melatonin }\end{array}$ \\
\hline \multicolumn{5}{|c|}{ 1-month old females } \\
\hline Body weight (g) & $16.2 \pm 1.9^{\mathrm{a}}$ & $15.0 \pm 1.2^{\mathrm{a}}$ & $15.9 \pm 0.7^{\mathrm{a}}$ & $15.3 \pm 1.4^{\mathrm{a}}$ \\
\hline Liver wet weight (mg) & $930 \pm 70^{\mathrm{a}}(-)$ & $850 \pm 60^{\mathrm{a}}(-)$ & $905 \pm 90^{\mathrm{a}}( \pm)$ & $900 \pm 70^{\mathrm{a}}(-)$ \\
\hline Kidneys wet weight (mg) & $200 \pm 20^{\mathrm{a}}(-)$ & $190 \pm 10^{\mathrm{a}}(-)$ & $185 \pm 20^{\mathrm{a}}(+)$ & $190 \pm 20^{\mathrm{a}}(-)$ \\
\hline $\begin{array}{l}\text { Cd intake } \\
(\mu \mathrm{g} / \mathrm{g} \text { body weight/day) }\end{array}$ & - & - & $9.8 \pm 0.9^{\mathrm{a}}$ & $9.0 \pm 0.6^{\mathrm{a}}$ \\
\hline \multicolumn{5}{|c|}{ 1-month old males } \\
\hline Body weight (g) & $19.9 \pm 2.3^{\mathrm{a}}$ & $15.5 \pm 1.4^{\mathrm{b}}$ & $20.0 \pm 2.0^{\mathrm{a}}$ & $15.8 \pm 1.2^{\mathrm{b}}$ \\
\hline Liver wet weight (mg) & $1070 \pm 10^{\mathrm{a}}(-)$ & $790 \pm 80^{\mathrm{b}}(-)$ & $1100 \pm 12^{\mathrm{a}}(-)$ & $800 \pm 90^{\mathrm{b}}(-)$ \\
\hline Kidneys wet weight (mg) & $250 \pm 20^{\mathrm{a}}(-)$ & $180 \pm 10^{\mathrm{b}}(-)$ & $253 \pm 20^{\mathrm{a}}(-)$ & $184 \pm 10^{\mathrm{b}}(-)$ \\
\hline $\begin{array}{l}\text { Cd intake } \\
(\mu \mathrm{g} / \mathrm{g} \text { body weight/day) }\end{array}$ & - & - & $14.6 \pm 2.0^{\mathrm{a}}$ & $13.8 \pm 1.0^{\mathrm{a}}$ \\
\hline \multicolumn{5}{|c|}{ 5-months old males } \\
\hline Body weight (g) & $22.5 \pm 3.1^{\mathrm{a}}$ & $21.3 \pm 3.4^{\mathrm{a}}$ & $22.1 \pm 2.9^{\mathrm{a}}$ & $21.5 \pm 0.7^{\mathrm{a}}$ \\
\hline Liver wet weight (mg) & $1160 \pm 120^{\mathrm{a}}(-)$ & $1022 \pm 290^{\mathrm{a}}(-)$ & $1171 \pm 110^{\mathrm{a}}(-)$ & $1035 \pm 70^{\mathrm{a}}(-)$ \\
\hline Kidneys wet weight (mg) & $260 \pm 40^{\mathrm{a}}(-)$ & $234 \pm 30^{\mathrm{a}}(-)$ & $258 \pm 20^{\mathrm{a}}(-)$ & $240 \pm 20^{\mathrm{a}}(-)$ \\
\hline $\begin{array}{l}\text { Cd intake } \\
(\mu \mathrm{g} / \mathrm{g} \text { body weight/day) }\end{array}$ & - & - & $21.0 \pm 4.0^{\mathrm{a}}$ & $49.5 \pm 8.0^{\mathrm{b}}$ \\
\hline
\end{tabular}

\#Values represent the mean $\pm \mathrm{SD}$ for $\mathrm{n}=6$. Bank voles received for 6 weeks control diet $(0.05 \mu \mathrm{g} / \mathrm{g})$ or diet contaminated with $\mathrm{Cd}(98-102 \mu \mathrm{g} / \mathrm{g})$. Means in the same line marked with different superscript letters are significantly different $(\mathrm{P}<0.05)$. Histopathology: $(+)$ - severe histopathological changes, $( \pm)$ - slight histopathological changes, (-) - normal morphology. 
Table 2. Tissue Cd accumulation, metallothionein and TBARS levels in the liver and kidney of 1-month old female bank voles ${ }^{\#}$

\begin{tabular}{lcccccc}
\hline Group & $\begin{array}{c}\text { Liver Cd } \\
(\mu \mathrm{g} / \mathrm{g})\end{array}$ & $\begin{array}{c}\text { Liver MT } \\
(\mu \mathrm{g} / \mathrm{g})\end{array}$ & $\begin{array}{c}\text { Liver } \\
\text { TBARS } \\
(\mathrm{nmol} / \mathrm{g})\end{array}$ & $\begin{array}{c}\text { Kidney Cd } \\
(\mu \mathrm{g} / \mathrm{g})\end{array}$ & $\begin{array}{c}\text { Kidney MT } \\
(\mu \mathrm{g} / \mathrm{g})\end{array}$ & $\begin{array}{c}\text { Kidney } \\
\text { TBARS } \\
(\mathrm{nmol} / \mathrm{g})\end{array}$ \\
\hline Control & $0.11 \pm 0.03^{\mathrm{a}}$ & $0.67 \pm 0.12^{\mathrm{a}}$ & $274 \pm 51^{\mathrm{a}}$ & $0.44 \pm 0.08^{\mathrm{a}}$ & $1.86 \pm 0.94^{\mathrm{a}}$ & $209 \pm 13^{\mathrm{a}}$ \\
Melatonin & $0.13 \pm 0.04^{\mathrm{a}}$ & $0.81 \pm 0.18^{\mathrm{a}}$ & $283 \pm 55^{\mathrm{a}}$ & $0.43 \pm 0.06^{\mathrm{a}}$ & $1.88 \pm 0.14^{\mathrm{a}}$ & $186 \pm 13^{\mathrm{a}}$ \\
Cd & $19.2 \pm 2.2^{\mathrm{b}}$ & $18.2 \pm 1.7^{\mathrm{b}}$ & $242 \pm 30^{\mathrm{a}}$ & $54.0 \pm 3.8^{\mathrm{b}}$ & $32.0 \pm 2.1^{\mathrm{b}}$ & $199 \pm 21^{\mathrm{a}}$ \\
& & & & & & $208 \pm 28^{\mathrm{a}}$
\end{tabular}

Source of variation: ANOVA - P values

\begin{tabular}{lcccccc} 
Cd & 0.0000 & 0.0000 & NS & 0.0000 & 0.0000 & NS \\
Melatonin & 0.0300 & 0.0262 & NS & 0.0000 & 0.0000 & NS \\
Cd $\times$ Melatonin & 0.0265 & 0.0165 & NS & 0.0000 & 0.0000 & NS \\
\hline
\end{tabular}

\#Values represent the mean $\pm \mathrm{SD}$ for $\mathrm{n}=6$. The 1 -month old female bank voles received for 6 weeks control diet $(0.05 \mu \mathrm{g} /$ g) or diet contaminated with $\mathrm{Cd}(98-102 \mu \mathrm{g} / \mathrm{g})$. Means in the same column marked with different superscript letters are significantly different $(\mathrm{P}<0.05)$. NS: non-significant. 
Table 3. Tissue Cd accumulation, metallothionein and TBARS levels in 1-month old male bank voles" ${ }^{\#}$

\begin{tabular}{lccccccc}
\hline Group & $\begin{array}{c}\text { Liver Cd } \\
(\mu \mathrm{g} / \mathrm{g})\end{array}$ & $\begin{array}{c}\text { Liver MT } \\
(\mu \mathrm{g} / \mathrm{g})\end{array}$ & $\begin{array}{c}\text { Liver } \\
\text { TBARS } \\
(\mathrm{nmol} / \mathrm{g})\end{array}$ & $\begin{array}{c}\text { Kidney Cd } \\
(\mu \mathrm{g} / \mathrm{g})\end{array}$ & $\begin{array}{c}\text { Kidney MT } \\
(\mu \mathrm{g} / \mathrm{g})\end{array}$ & $\begin{array}{c}\text { Kidney } \\
\text { TBARS } \\
(\mathrm{nmol} / \mathrm{g})\end{array}$ & $\begin{array}{c}\text { Duodenum Cd } \\
(\mu \mathrm{g} / \mathrm{g})\end{array}$ \\
\hline Control & $0.09 \pm 0.04^{\mathrm{a}}$ & $1.14 \pm 0.60^{\mathrm{a}}$ & $220 \pm 40^{\mathrm{a}}$ & $0.20 \pm 0.07^{\mathrm{a}}$ & $1.65 \pm 0.35^{\mathrm{a}}$ & $211 \pm 30^{\mathrm{a}}$ & $0.14 \pm 0.06^{\mathrm{a}}$ \\
Melatonin & $0.09 \pm 0.03^{\mathrm{a}}$ & $1.11 \pm 0.45^{\mathrm{a}}$ & $195 \pm 15^{\mathrm{a}}$ & $0.22 \pm 0.10^{\mathrm{a}}$ & $1.47 \pm 0.25^{\mathrm{a}}$ & $220 \pm 19^{\mathrm{a}}$ & $0.11 \pm 0.07^{\mathrm{a}}$ \\
$\mathrm{Cd}$ & $16.6 \pm 1.6^{\mathrm{b}}$ & $25.5 \pm 2.4^{\mathrm{b}}$ & $186 \pm 17^{\mathrm{a}}$ & $30.5 \pm 4.5^{\mathrm{b}}$ & $35.5 \pm 4.0^{\mathrm{b}}$ & $202 \pm 25^{\mathrm{a}}$ & $12.10 \pm 1.50^{\mathrm{b}}$ \\
$\mathrm{Cd}+$ Melatonin & $13.3 \pm 2.2^{\mathrm{c}}$ & $14.5 \pm 1.3^{\mathrm{c}}$ & $180 \pm 20^{\mathrm{a}}$ & $19.6 \pm 3.5^{\mathrm{c}}$ & $18.2 \pm 2.0^{\mathrm{c}}$ & $210 \pm 20^{\mathrm{a}}$ & $7.20 \pm 1.45^{\mathrm{c}}$
\end{tabular}

Source of variation: ANOVA - $\mathrm{P}$ values

\begin{tabular}{|c|c|c|c|c|c|c|c|}
\hline $\mathrm{Cd}$ & 0.0000 & 0.0000 & NS & 0.0000 & 0.0000 & NS & 0.0000 \\
\hline Melatonin & 0.0102 & 0.0000 & NS & 0.0000 & 0.0000 & NS & 0.0000 \\
\hline $\mathrm{Cd} \times$ Melatonin & 0.0112 & 0.0000 & NS & 0.0000 & 0.0000 & NS & 0.0000 \\
\hline
\end{tabular}

\#Values represent the mean $\pm \mathrm{SD}$ for $\mathrm{n}=6$. The 1 -month old male bank voles received for 6 weeks control diet $(0.05 \mu \mathrm{g} /$ g) or diet contaminated with $\mathrm{Cd}(98-102 \mu \mathrm{g} / \mathrm{g})$. Means in the same column marked with different superscript letters are significantly different $(\mathrm{P}<0.05)$. NS: non-significant. 
Table 4. Tissue Cd accumulation, metallothionein and TBARS levels in 5-months old male bank voles ${ }^{\#}$

\begin{tabular}{|c|c|c|c|c|c|c|c|}
\hline & $\begin{array}{l}\text { Liver Cd } \\
(\mu \mathrm{g} / \mathrm{g})\end{array}$ & $\begin{array}{l}\text { Liver MT } \\
(\mu \mathrm{g} / \mathrm{g})\end{array}$ & $\begin{array}{c}\text { Liver } \\
\text { TBARS } \\
(\mathrm{nmol} / \mathrm{g})\end{array}$ & $\begin{array}{l}\text { Kidney Cd } \\
(\mu \mathrm{g} / \mathrm{g})\end{array}$ & $\begin{array}{l}\text { Kidney MT } \\
(\mu \mathrm{g} / \mathrm{g})\end{array}$ & $\begin{array}{l}\text { Kidney } \\
\text { TBARS } \\
(\mathrm{nmol} / \mathrm{g})\end{array}$ & $\begin{array}{c}\text { Duodenum } \mathrm{Cd} \\
(\mu \mathrm{g} / \mathrm{g})\end{array}$ \\
\hline Control & $0.12 \pm 0.08^{\mathrm{a}}$ & $0.59 \pm 0.12^{\mathrm{a}}$ & $241 \pm 38^{\mathrm{a}}$ & $0.24 \pm 0.06^{\mathrm{a}}$ & $2.16 \pm 0.37^{\mathrm{a}}$ & $240 \pm 19^{\mathrm{a}}$ & $1.89 \pm 0.36^{\mathrm{a}}$ \\
\hline Melatonin & $0.09 \pm 0.07^{\mathrm{a}}$ & $0.63 \pm 0.06^{\mathrm{a}}$ & $255 \pm 21^{\mathrm{a}}$ & $0.24 \pm 0.07^{\mathrm{a}}$ & $2.18 \pm 0.33^{\mathrm{a}}$ & $248 \pm 32^{\mathrm{a}}$ & $1.48 \pm 0.32^{\mathrm{a}}$ \\
\hline $\mathrm{Cd}$ & $9.9 \pm 2.5^{\mathrm{b}}$ & $8.9 \pm 1.1^{\mathrm{b}}$ & $261 \pm 33^{\mathrm{a}}$ & $16.0 \pm 3.3^{\mathrm{b}}$ & $14.4 \pm 3.8^{\mathrm{b}}$ & $247 \pm 5^{a}$ & $19.49 \pm 2.69^{\mathrm{b}}$ \\
\hline $\mathrm{Cd}+$ Melatonin & $16.3 \pm 3.0^{c}$ & $16.4 \pm 1.6^{\mathrm{c}}$ & $241 \pm 33^{\mathrm{a}}$ & $29.0 \pm 7.0^{\mathrm{c}}$ & $23.9 \pm 4.0^{\mathrm{c}}$ & $260 \pm 22^{\mathrm{a}}$ & $28.38 \pm 4.42^{\mathrm{c}}$ \\
\hline
\end{tabular}

Source of variation: ANOVA - P values

\begin{tabular}{lccccccc} 
Cd & 0.0000 & 0.0000 & NS & 0.0000 & 0.0000 & NS & 0.0000 \\
Melatonin & 0.0008 & 0.0000 & NS & 0.0011 & 0.0000 & NS & 0.0000 \\
Cd $\times$ Melatonin & 0.0007 & 0.0000 & NS & 0.0011 & 0.0000 & NS & 0.0000 \\
\hline
\end{tabular}

\#Values represent the mean $\pm \mathrm{SD}$ for $\mathrm{n}=6$. The 5 -months old male bank voles received for 6 weeks control diet $(0.05 \mu \mathrm{g} /$ g) or diet contaminated with $\mathrm{Cd}(98-102 \mu \mathrm{g} / \mathrm{g})$. Means in the same column marked with different superscript letters are significantly different $(\mathrm{P}<0.05)$. NS: non-significant. 


\section{DISCUSSION}

The present study clearly demonstrates that exogenously administered melatonin in drinking water to one month old (young) bank voles decreases $\mathrm{Cd}$ accumulation in their liver and kidneys and this effect is opposite to that observed in animals subcutaneously administered with melatonin (CHWEŁATIUK et al. 2005). It has been shown that subcutaneously administered melatonin increases concentration of $\mathrm{Cd}$ in one month old bank vole tissues through its indirect influence on body weight as well as mass-specific efficiency of digestion and absorption processes in the alimentary tract (WŁostowsKi et. al. 2005). In contrast, in the present study, orally administered melatonin decreases $\mathrm{Cd}$ accumulation in the liver and kidneys of young bank voles in a very similar way as was observed earlier in the laboratory mouse (Table 2 and 3; Chwęatiuk et al. 2006). The mechanism by which an orally administered melatonin influences cadmium concentration in photosensitive bank voles is not known so far. Of great biological importance is melatonin ability to form complexes with metals. An adsorptive cathodic stripping voltammetry showed that melatonin binds and immobilizes cadmium (Limson et al. 1998). Thus, it cannot be excluded that melatonin forming complexes with cadmium in the intestine inhibits absorption of this metal and as a consequence decreases its tissue concentration. A substantial decline of $\mathrm{Cd}$ concentration in duodenum supports this possibility (Table 3). Furthermore, the metal binding role of melatonin is favored by its unusual amphiphilic nature. Melatonin is both highly lipophilic as well as soluble in aqueous media, which makes this compound able to cross lipid bilayers (Costa et al. 1997). Furthermore, because of high permeability of cellular and morphophysiological barriers to melatonin (Limson et al. 1998), it can be also assumed that this compound may facilitate the removal of $\mathrm{Cd}$ from the kidneys and other tissues. However, to elucidate this possibility more precise analysis is necessary.

Due to the decreased renal $\mathrm{Cd}$ level in melatonin co-treated females, no degenerative changes in that tissue were observed (Table 1). Total Cd accumulation is closely related to the fraction of highly reactive non-MT-bound Cd, considered as being responsible for generation of free radicals and lipid peroxidation, therefore any decrease of total $\mathrm{Cd}$ concentration should result in reduction of this fraction of $\mathrm{Cd}$. This supposition, which may be of great importance, requires further research. Furthermore, because melatonin is an effective antioxidant and free radicals scavenger, there was a possibility that this compound might have decreased the Cd-induced oxidative stress. However, data from the present work revealed that melatonin did not act in that manner, because in spite of the presence of pathological changes in the kidneys of females no rise in the level of lipid peroxidation was noted (Table 2). It should be pointed out that antioxidant properties of melatonin were not confirmed either in previous research concerned with laboratory mice (CHWEtatiuk et al. 2006). Thus, data obtained in this work suggest that orally administered mela- 
tonin has prevented $\mathrm{Cd}$-induced renal degeneration primarily due to its ability to reduce total tissue $\mathrm{Cd}$ accumulation.

The occurrence of Cd-induced histopathological changes exclusively in the kidneys of female bank voles from the Cd-alone group confirms literature data which indicate that females are more sensitive to Cd-toxicity than males. Enhanced susceptibility to Cd-toxicity of females is probably associated with their greater tissue accumulation of the metal than males (Blazka and SHaikH 1991). There is an assumption that endocrine hormones such as progesterone and estradiol might be responsible for the sex differences in $\mathrm{Cd}$ distribution (Shimada et al. 1997). Progesterone as the agonist of $\mathrm{Ca}^{2+}$ channels, one of the transport pathways of nonessential $\mathrm{Cd}$ into a cell, enhances $\mathrm{Cd}^{2+}$ influx resulting in the increased tissue concentration and toxicity of this metal (BRIDGES and ZaLups 2005). Estradiol is also an important hormone in regulation of cadmium disposition as well as its toxicity (BLAZKa and SHAiKh 1991). It is suggested that the increased concentration of this metal influenced by this hormone is probably through reducing Cd-induced MT synthesis (Sogawa et al. 2001a, b). Thus, the higher tissue accumulation and toxicity of cadmium in female voles than in males might be caused by the female sex hormones.

The data obtained in this work clearly indicate that the age-dependent tissue Cd accumulation (RummLer et al. 1989) is significantly influenced by melatonin. We showed that orally administered melatonin possesses an opposite effect on Cd concentration in young (one month old) and old (five months old) bank voles. In young voles housed in long photoperiod conditions and simultaneously exposed to melatonin in drinking water, decreased hepatic and renal $\mathrm{Cd}$ accumulation was noted (Table 3 ), while in old animals, increased tissue $\mathrm{Cd}$ concentration was observed (Table 4). It is also noteworthy that old bank voles held from the moment of birth in the long photoperiod and transferred after five months to the short photoperiod showed notably higher $\mathrm{Cd}$ concentration in their tissues than those remaining in long photoperiod (unpublished data). Thus, orally administered melatonin increases hepatic and renal Cd-concentration only in old bank voles. That increase of tissue $\mathrm{Cd}$ accumulation is probably related to higher intake of Cd-contaminated food, and it is evidenced by the fact that old voles exposed to melatonin or short photoperiod consumed more food (154-259\%) than young bank voles (Table 1). Because of the similar amount of melatonin intake by young and old rodents (about $2 \mu \mathrm{g} / \mathrm{g}$ b.w. $/ 24 \mathrm{~h}$ ), it is possible, that in comparison with younger voles, in older ones a higher amount of non-melatonin bound cadmium ions were present in the alimentary tract, able to easily cross through enterocytes to the blood stream and tissues. Thus, melatonin increases $\mathrm{Cd}$ accumulation in tissues of five months old bank voles probably mainly through higher consumption of Cd-contaminated food.

The mechanism of melatonin-increased food consumption by old bank voles is unclear. Mustonen et al. (2002) revealed that this indoleamine also stimulates the consumption of food in tundra voles (Microtus oeconomus). Moreover, these authors showed that melatonin stimulates secretion of ghrelin, 
a compound responsible for enhancing food consumption. This 28-amino acid hormone produced in the stomach indirectly influences the satiety center (NTS - nucleus tratus solitarius) localized in the brain stem. The activity of NTS is regulated on the one hand by vagus nerve and spinal nerves with sensory branches localized in the gastrointestinal tract and on the other hand through neurons of the arcuate nucleus in the hypothalamus. The arcuate nucleus contains two major types of neurons with opposing actions: NPY/AgRP cells which inhibit the satiety center as well as stimulate appetite and food intake, and POMC/CART neurons which stimulate the satiety center and inhibit eating (Marx 2003, ANUKulkitch et al. 2007). The cellular membranes of both types of neurons consist of molecular receptors regulated by signaling molecules. NPY/ AgRP neurons stimulated by ghrelin for instance, produce neuropeptide $\mathrm{Y}$ which stimulate secondary neurons in hypothalamus inhibiting NTS and stimulating appetite. Thus, melatonin-induced higher food intake by old bank voles possibly is caused by the influence of this indoleamine on the ghrelin synthesis in the vole stomach and as the consequence on the NTS activity. The reason why melatonin exerts its stimulating effect on food intake only in old bank voles is not known yet. Although the blood ghrelin level was not measured in present work, it cannot be excluded that the level of this hormone in blood of old bank voles was higher than in younger ones. That assumption is in accordance with literature data which indicate the age-dependent rise of ghrelin concentration in blood and its mRNA expression (Gualillo et al. 2001, SAKATA et al. 2002). Another possible explanation is that the amount of molecular ghrelin receptors on NPY/AgRP cells in the hypothalamus arcuate nucleus is higher in older than in younger animals. It is also possible that melatonin might act on arcuate nucleus neurons directly and in that way might exert its effect on the satiety center in the brain stem. However, to elucidate the precise mechanism(s) of melatonin action in the regulation of food intake in that rodent, more research is needed.

In conclusion, the data of this study clearly demonstrate that orally administered melatonin to one month old female and male bank voles reduces tissue $\mathrm{Cd}$ accumulation probably through forming complexes with the metal which are not absorbed in the intestine. On the contrary, in five months old voles melatonin increases tissue $\mathrm{Cd}$ concentration possibly through increasing consumption of Cd-contaminated food.

\section{MELATONINA PODAWANA DOUSTNIE A AKUMULACJA I TOKSYCZNOŚĆ KADMU U NORNICY RUDEJ (MYODES GLAREOLUS)}

\section{SUMMARY}

Wiek oraz płeć zwierząt są istotnymi czynnikami wpływającymi na akumulację i toksyczność metali ciężkich, w tym kadmu. Celem pracy było sprawdzenie wpływu doustnie podawanej melatoniny, znanego antyoksydanta i chelatora metali, na akumulację i toksyczność kadmu u jednomiesięcznych (młodych) oraz pięciomiesięcznych (starych) nornic rudych spożywających pokarm zawierający kadm $(100 \mu \mathrm{g} / \mathrm{g})$. Po sześciu tygodniach 
eksperymentu nastąpiło obniżenie akumulacji kadmu w wątrobie (17 i 20\%) i nerkach (39 i 36\%) odpowiednio u młodych samic i samców spożywających melatoninę i kadm w porównaniu do zwierząt spożywających wyłącznie kadm, natomiast $\mathrm{u}$ dorosłych zwierząt wzrosła akumulacja kadmu w wątrobie $(65 \%)$ i nerkach $(81 \%)$ oraz spożycie pokarmu skażonego kadmem $(136 \%)$ bez istotnych zmian w ciężarze ciała. Uzyskane wyniki wskazują, że melatonina podawana wraz z kadmem per os u młodych nornic obniża akumulację kadmu w tkankach prawdopodobnie poprzez tworzenie kompleksów z metalem, natomiast u dorosłych zwierząt zwiększa koncentrację tego metalu stymulując spożycie pokarmu zawierającego kadm.

Słowa kluczowe: akumulacja kadmu, melatonina, chelatowanie metali, płeć, wiek

\section{REFERENCES}

Andersen O. 2004a: Chemical and biological considerations in the treatment of metal intoxications by chelating agents. Mirev. Med. Chem. 4: 159-165.

Andersen O., Nielsen J.B., Nordberg G.F. 2004b: Nutritional interactions in intestinal cadmium uptake - possibilities for risk reduction. BioMetals 17: 543-547.

Anukulkitch Ch., Rao A., Dunshea F.R., Blache D., Lincoln G.A., Clarke I. 2007: Influence of photoperiod and gonadal status on food intake, adiposity, and gene expression of hypothalamic appetite regulators in a seasonal mammal. Am. J. Physiol. Regul. Inter. Comp. Physiol. 292: R242-R252.

Blazka M.E., Shaikh Z.A. 1991: Sex differences in hepatic and renal cadmium accumulation and metallothionein induction. Role of estradiol. Biochem. Pharmacol. 41(5): 775-780.

Bonda E., WŁostowski T., Krasowska A. 2004: Testicular toxicity induced by dietary cadmium is associated with decreased testicular zinc and increased hepatic and renal metallothionein and zinc in the bank vole. BioMetals 17: 615-624.

Bridges Ch.C., Zalups R.K. 2005: Molecular and ionic mimicry and the transport of toxic metals. Toxicol. Appl. Pharmacol. 204: 274-308.

Brzóska M.M., MoniuszKo-Jakoniuk J. 1998: The influence of calcium content in diet on cumulation and toxicity of cadmium in the organism. Arch. Toxicol. 72: 63-73.

Chwelatiuk E., WŁostowski T., Krasowska A., Bonda E. 2005: Melatonin increases tissue accumulation and toxicity of cadmium in the bank vole (Clethrionomys glareolus). BioMetals 18: 283-291.

Chwęatiuk E., WŁostowski T., Krasowska A., Bonda E. 2006: The effect of orally administered melatonin on tissue accumulation and toxicity of cadmium in mice. J. Trace Elem. Med. Biol. 19: 259-265.

Costa E.J.X., Shida C.S., Biaggi M.H., Ito A.S., Lamy Freund M.T. 1997: How melatonin interacts with lipid bilayers: a study by fluorescence and ESR spectroscopies. FEBS Lett 416: 103-106.

Goyer R.A., Miller C.R., Zhu S.Y., Victery W. 1989: Non-metallothionein-bound cadmium in the pathogenesis of cadmium nephrotoxicity in the rat. Toxicol. Appl. Pharmacol. 101: 232-244.

Groten J.P., Sinkeldam E.J., Luten J.B., van Bladeren P.J. 1991: Cadmium accumulation and metallothionein concentrations after 4-week dietary exposure to cadmium chloride or cadmium-metallothionein in rats. Toxicol. Appl. Pharmacol. 111: $504-513$. 
Gualillo O., Caminos J.E., Kojima M., Kangawa K., Arvat E., Ghigo E., Casanueva F.F., DiÉGuez C. 2001: Gender and gonadal influences on ghrelin mRNA levels in rat stomach. Eur. J. Endocrinol. 144: 687-690.

Karbownik M., Lewinski A., Reiter R.J. 2001: Anticarcinogenic actions of melatonin which involve antioxidative processes: comparision with other antioxidants. Int. J. Biochem. Cell Biol. 33: 735-753.

Klaassen C.D., Liu J., Choudhuri S. 1999: Metallothionein: an intracellular protein to protect against cadmium toxicity. Annu. Rev. Pharmacol. Toxicol. 39: 267-294.

Limson J., Nyokong T., Daya S. 1998: The interaction of melatonin and its precursors with aluminium, cadmium, copper, iron, lead, and zinc: an adsorptive voltammetric study. J. Pineal Res. 24: 15-21.

MarX J. 2003: Cellular warriors at the battle of the bulge. Science 299: 846-849.

Min K., Kobayashi K., Onosaka S., Ohta N., Okada Y., Tanaka K. 1986: Tissue distribution of cadmium and nephropathy after administration of cadmium in several chemical forms. Toxicol. Appl. Pharmacol. 86: 262-270.

Mustonen A.M., Nieminen P., Hyvärinen H. 2002: Melatonin and the wintering strategy of the tundra vole, Microtus oeconomus. Zoolog. Sci. 19: 683-687.

Nordberg M., Nordberg G.F. 2000: Toxicological aspects of metallothionein. Cell Mol. Biol. 46: 451-463.

Ohкawa H., Ohiski N., Yagi K. 1979: Assay for lipid peroxides in animal tissues by thiobarbituric acid reaction. Anal. Biochem. 95: 351-358.

Onosaka S., Cherian M.G. 1982: Comparison of metallothionein determination by polarographic and cadmium saturation methods. Toxicol. Appl. Pharmacol. 63: $270-274$.

Pieri C., Moroni F., Marra M., Marcheselli F., Recchioni R. 1995: Melatonin is an efficient antioxidant. Arch. Gerontol. Geriatr. 20: 159-165.

Reeves P.G., Chaney R.L. 2004: Marginal nutritional status of zinc, iron, and calcium increases cadmium retention in the duodenum and other organs of rats fed rice-based diets. Environ. Res. 96: 311-322.

Reiter R.J., Tan D.X., Terron M.P., Flores L.J., Czarnocki Z. 2007: Melatonin and its metabolites: new findings regarding their production and their scavenging actions. Acta Biochim. Pol. 54: 1-9.

Rummler H.G., Classen H.G., Schimatsechek H.F., Thöni H., Schumacher E., Schenkel H., Vormann J., Günter T. 1989: Age-dependent accumulation of cadmium in rats exposed to contaminated drinking water; interactions with zinc and cooper and subcellular $\mathrm{Cd}$ distribution in kidney cells. J. Trace Elem. Electrolytes Health Dis. 3: 217-223.

Sakata I., Tanaka T., Matsubara M., Yamazaki M., Tani S., Hayashi Y., Kangawa K., SAKAI T. 2002: Postnatal changes in ghrelin mRNA expression and in ghrelinproducing cells in the rat stomach. J. Endocrinol. 174: 463-471.

Satarug S., Baker J. R., Urbenjapol S., Haswell-Elkins M., Reilly P.E.B., Williams D.J., Moore M.R. 2003: A global perspective on cadmium pollution and toxicity in non-occupationally exposed population. Toxicol. Lett. 137: 65-83.

Shimada H., Bare R.M., Hochadel J.F., WaAlkes M.P. 1997: Testosterone pretreatment mitigates cadmium toxicity in male $\mathrm{C} 57$ but not in $\mathrm{C} 3 \mathrm{H}$ mice. Toxicology $\mathbf{1 1 6}$ : 183-191.

Sogawa N., Onodera K., Sogawa C. A., Mukubo Y., Fukuoka H., Oda N., Furuta H. 2001a: Bisphenol A enhances cadmium toxicity through estrogen receptor. Methods Find Exp. Clin. Pharmacol. 23(7): 395-399. 
Sogawa N., Sogawa C.A., Oda N., Fujioka T., Onodera K., Furuta H. 2001b: The effects of ovariectomy and female sex hormones on hepatic metallothioneinI gene expression after injection of cadmium chloride in mice. Pharmacol. Res. 44(1): 53-57.

Waisberg K., Joseph P., Hale B., Beyersmann D. 2003: Molecular and cellular mechanisms of cadmium carcinogenesis. Toxicology 192: 95-117.

Winge D.R., Miklossy K.A. 1982: Domain nature of metallothionein. J. Biol. Chem. 257: 3471-3476.

WŁostowski T., Krasowska A. 1999: Subcellular distribution of metallothionein and cadmium in the liver and kidneys of bank voles (Clethrionomys glareolus) exposed to dietary cadmium. BioMetals 12: 173-179.

WŁostowski T., Krasowska A., Łaszkiewicz-Tiszczenko B. 2000: Dietary cadmium induces histopathological changes despite a sufficient metallothionein level in the liver and kidneys of the bank vole (Clethrionomys glareolus). Comp. Biochem. Physiol. C 126: 21-28.

WŁostowski T., Bonda E., Krasowska A. 2004: Photoperiod affects hepatic and renal cadmium accumulation, metallothionein induction, and cadmium toxicity in the wild bank vole (Clethrionomys glaeolus). Ecotoxicol. Environ. Saf. 58: 29-36.

WŁostowski T., ChweŁatiuk E., Bonda E., Krasowska A., Żukowski J. 2005: Hepatic and renal cadmium accumulation is associated with mass-specific daily metabolic rate in the bank vole (Clethrionomys glareolus). Comp. Biochem. Physiol C 141: 15-19.

Zalups R.K., Ahmad S. 2003: Molecular handling of cadmium in transporting epithelia. Toxicol. Appl. Pharmacol. 186: 163-188. 